\title{
PENERAPAN MODEL PEMBELAJARAN KOOPERATIF BERBANTUAN MEDIA GAMBAR UNTUK MENINGKATKAN PENGUASAAN MEMBUAT KALIMAT BAHASA JEPANG SISWA KELAS X IBB 1 SMA CANDIMAS PANCASARI TAHUN AJARAN 2018/2019
}

\author{
N.K. Sudiarini ${ }^{1}$ G.S. Hermawan ${ }^{2}$ D.M.S.Mardani ${ }^{3}$ \\ ${ }^{123}$ Jurusan Pendidikan Bahasa Jepang, Universitas Pendidikan Ganesha, Singaraja,Bali \\ e-mail: ni.kadek.sudiarini@undiksha.ac.id \\ satya.hermawan@undiksha.ac.id desak.mardani@undiksha.ac.id
}

\begin{abstract}
Abstrak
Penelitian ini bertujuan untuk menganalisis 1) peningkatan penguasaan membuat kalimat bahasa Jepang siswa dan 2) mendeskripsikan respons siswa setelah diterapkan model pembelajaran kooperatif berbantuan media gambar. Jenis penelitian ini adalah penelitian tindakan kelas yang dilaksanakan dalam dua siklus. Subjek pada penelitian ini adalah siswa kelas X IBB 1 SMA Candimas Pancasari tahun ajaran 2018/2019 yang berjumlah 36 orang siswa. Metode pengumpulan data yang digunakan pada penelitian ini adalah observasi, tes, dan angket. Data yang telah terkumpul dianalisis dengan teknik analisis data secara deskriptif kualitatif dan kuantitatif. Hasil penelitian ini menunjukkan bahwa rata-rata pre-test siswa adalah 32,88 dengan ketuntasan klasikal yaitu 5,56\%. Pada siklus I rata-rata siswa menjadi 83,36 dan ketuntasan klasikal menjadi $69,44 \%$. Pada siklus II rata-rata siswa meningkat menjadi 94 dengan ketuntasan klasikal sebesar 100\%. Dan respons siswa tergolong positif, dengan rata-rata 36 pada siklus I dan 37 pada siklus II. Sehingga dapat disimpulkan bahwa, penerapan model pembelajaran kooperatif berbantuan media gambar efektif untuk meningkatkan penguasaan membuat kalimat bahasa Jepang siswa.
\end{abstract}

Kata kunci: model pembelajaran kooperatif, media gambar, membuat kalimat bahasa Jepang.

要旨

本研究の目的は、1) 学習者の日本語文を作る能力を向上されるための絵カードを使用した協同学習 方法の応用を知ること、2) 学習者の反応を説明することである。研究は二周期に教室実践活動調査 である。研究の対象は2018/2019年度パンチャサリ・チャンディマス高等学校言語コース十年生一組 の三十六名である。データ収集の方法は観察、テスト、アンケートで行った。データは定量的および 定性的な記述法により分析した。結果は、予備テストで標準を越えた学習者の割合は5,56\%で、平均 点が32,88点だったのに対し、第一周期終了時では69,44\%、平均点が83,36点、第二周期終了時では $100 \%$ 、平均点が94点に上がったからいえる。また、学習者の反応は良好と言える。第一周期では学 習者の反応の平均点は36点で、第二周期では学習者の反応の平均点は37点である。以上ことから、 絵カードを使用した協同学習方法は学習者の日本語文を作る能力を向上されたの効果的であると言え る。

キーワード：協同学習方法、絵カード、日本語文を作る 


\section{Pendahuluan}

Di Indonesia pelajaran bahasa Jepang mendapat respon positif dikalangan pebelajar. Hal ini dibuktikan dengan jumlah pebelajar bahasa Jepang di Indonesia terus mengalami peningkatan. Menurut Sutedi (2013) jumlah pebelajar bahasa Jepang di Indonesia menduduki posisi ke dua di dunia setelah Cina. Dibalik banyaknya peminat bahasa Jepang di Indonesia tidak sedikit dari pebelajar yang mengeluh karena tidak mampu menguasai bahasa Jepang dengan baik. Salah satu menyebabnya adalah rendahnya penguasaan siswa dalam kalimat bahasa Jepang. Dalam penelitian Istiqomah (2015) menyatakan bahwa $79,3 \%$ dari 47 orang siswa mengalami kesulitan dalam memahami pola kalimat bahasa Jepang terutama dalam membuat kalimat bahasa Jepang yang benar. Penelitian yang dilakukan Ahdiyani (2015) juga menyebutkan hal yang sama dari 25 orang siswa $73 \%$ mengeluhkan susahnya memahami kalimat bahasa Jepang.

Kesulitan dalam memahami kalimat bahasa Jepang juga dialami oleh siswa kelas X IBB 1 . Berdasarkan hasil wawancara dan observasi ditemukan faktor utama yang menjadi kendala dalam penguasaan membuat kalimat bahasa Jepang adalah perbedaan struktur kalimat bahasa Indonesia dengan bahasa Jepang, meliputi: kesalahan dalam menempatkan partikel "wa" dan "no" dalam kalimat yang menyatakan kepemilikan, kesulitan dalam membuat kalimat bahasa Jepang yang sesuai dengan pola kalimat bahasa Jepang, kebingungan dalam memahami penggunaan kata tunjuk "kore, sore, dan are" dengan "koko, soko, dan asoko" dalam kalimat yang menunjukan tempat dengan benda, dan kebingungan dalam menggunakan ungkapan "dewa arimasen" dan "sou dewa arimasen" pada kalimat pernyataan.

Permasalahan lainnya yang ditemukan adalah siswa cenderung kurang fokus dalam mengikuti pembelajaran, mereka merasa jenuh dan kurang aktif dalam pembelajaran bahkan banyak siswa yang mengobrol dengan temannya. Selain itu siswa lebih mudah belajar berkelompok dibandingkan belajar individu.

Hasil dari pre-test kelas X IBB 1 yang tergolong rendah dari 36 siswa 34 siswa belum mencapai Kriteria Ketuntasan Minimal (KKM) yang telah ditetapkan dengan nilai rata-rata kelas sebesar 32.88 .

Dari pemaparan tersebut menandakan bahwa perlu adanya metode pembelajaran yang lebih inovatif dan menarik untuk membangkitkan semangat belajar siswa, mengurangi kebosanan, meningkatkan konsentrasi siswa, dan mendorong siswa untuk aktif dalam mengikuti pembelajaran sehingga penguasaan membuat kalimat bahasa Jepang siswa meningkat.

Model pembelajaran yang tepat dengan karakteristik siswa kelas X IBB 1 adalah model pembelajaran kooperatif. Menurut Gilies (2014) menyatakan bahwa pembelajaran kooperatif membantu siswa dalam meningkatkan prestasi akademik dan pembentukan jiwa sosial. Dengan demikian pembelajaran kooperatif, memberikan kemudahan bagi siswa untuk saling bertukar informasi, saling membimbing dan saling membantu apabila ada temannya yang mengalami kesulitan. Selain itu pembelajaran kooperatif juga memberikan kebebasan kepada siswa untuk mengemukakan pendapat karena saat belajar bersama teman tidak ada rasa canggung, rasa malu, takut salah atau tertekan. Model pembelajaran kooperatif tidak hanya unggul dalam membantu siswa memahami konsep yang sulit, tetapi juga sangat berguna untuk menumbuhkan kemampuan berpikir kritis, mendorong siswa untuk terlibat aktif pada proses pembelajaran sehingga memberikan dampak positif terhadap kualitas interaksi dan komunikasi siswa.

Dalam penerapan model pembelajaran kooperatif diperlukan media penunjang, untuk membantu guru dalam menjelaskan materi pola kalimat bahasa Jepang dan memudahkan siswa ketika berlatih membuat kalimat bahasa Jepang serta menciptakan suasana belajar yang lebih menyenangkan. Selain itu, pemilihan media pembelajaran harus disesuaikan dengan kebutuhan siswa dan fasilitas sekolah. Melihat karakteristik siswa kelas X IBB 1 dan model pembelajaran kooperatif yang akan diterapkan, maka media gambar dianggap sesuai untuk mengatasi masalah tersebut.

Media gambar bertujuan untuk menarik perhatian, memperjelas materi, mengilustrasikan fakta dan informasi (Kusnandi dan Sujtipto, 2013:41). Melalui media gambar akan memberikan pengarahan dan bayangan kepada siswa mengenai materi pelajaran, sehingga 
materi yang didapat oleh siswa lebih faktual, berkesan dan tidak mudah dilupakan, menarik perhatian siswa sehingga siswa lebih fokus kepada pembelajaran serta mengurangi kebosanan siswa di dalam kelas. Disamping itu ada beberapa pertimbangan dalam pemilihan media gambar diantaranya: media gambar mudah didapat, mudah dibawa kemana-mana, murah dan realistik, media gambar mudah dipahami oleh berbagai kalangan usia, serta media gambar memudahkan siswa dalam memahami konsep kalimat bahasa Jepang.

Penelitian tentang penerapan model pembelajaran kooperatif pernah dilakukan oleh Dewi, dkk (2015) yang menunjukkan bahwa model pembelajaran kooperatif sangat efektif di terapkan dalam pemahaman tata bahasa dasar bahasa Jepang. Penelitian tentang penggunaan media gambar pernah dilakukan oleh Diner (2009) yang mengungkapkan bahwa penggunaan media gambar efektif untuk meningkatkan hasil belajar mahasiswa dan Mardani (2012) yang mengungkapkan bahwa pemanfaatan media visual (gambar) dapat meningkatkan kemampuan menulis huruf Hiragana dan Katakana dengan indah pada mahasiswa Jurusan Pendidikan Bahasa Jepang.

Berdasarkan pemaparan tersebut model pembelajaran kooperatif yang dikombinasikan dengan media gambar dianggap tepat dalam mengatasi permasalahan penguasaan membuat kalimat bahasa Jepang pada kelas X IBB 1 SMA Candimas Pancasari, karena model pembelajaran dan media tersebut sesuai dengan kondisi kelas serta karakteristik dan kebutuhan siswa yang dijadikan tempat penelitian

Berdasarkan uraian tersebut, penelitian ini akan membahas dua hal yaitu: 1) Apakah penerapan model pembelajaran kooperatif berbantuan media gambar dapat meningkatkan penguasaan pola kalimat bahasa Jepang pada siswa kelas X IBB 1 SMA Candimas Pancasari Tahun Ajaran 2018/2019. 2) Bagaimana respon siswa terhadap penguasaan pola kalimat bahasa Jepang setelah diterapkan model pembelajaran kooperatif berbantuan media gambar. Maka tujuan penelitian ini adalah untuk meningkatkan penguasaan pola kalimat bahasa Jepang dengan menerapkan model pembelajaran kooperatif berbantuan media gambar pada siswa kelas X IBB 1 SMA Candimas Pancasari Tahun Ajaran 2018/2019 dan untuk mendeskripsikan respon siswa terhadap penerapan model pembelajaran kooperatif berbantuan media gambar dalam meningkatkan penguasaan pola kalimat bahasa Jepang.

\section{Metode}

Penelitian ini merupakan Penelitian Tindakan Kelas yang dilaksanakan dengan multi sklus. Setiap siklus dirancang dalam tiga kali pertemuan, dua kali pertemuan untuk pemberian materi dan satu kali pertemuan untuk pemberian post-test. Siklus dalam penelitian ini menggunakan model dari Sanjaya (2012) yang terdiri dari empat tahapan yaitu: perencanaan, pelaksanaan, observasi dan evaluasi, dan refleksi.

Prosedur penelitian ini dimulai dari refleksi awal untuk mengidentifikasi masalah yang dihadapi oleh siswa dalam pembelajaran. Dilanjutkan pada tahap perencanaan yang terdiri atas: menganalisis silabus, menyusun RPP, mempersiapkan media gambar, menyusun lembar observasi, menyusun format evaluasi berupa tes, dan menyusun butir-butir angket untuk mengetahui tanggapan siswa.

Pelaksanaan tindakan terdiri atas tiga kegiatan pokok. 1) penyampaian tujuan pembelajaran, penjelasan pokok-pokok materi dan pembentukan kelompok belajar. 2) penjelasan materi, pembagian gambar kepada masing-masing kelompok, latihan membuat kalimat bahasa Jepang dengan menggunakan media gambar dan presentasi kelompok serta evaluasi. 3) menyimpulkan isi pembelajaran dan pemberian penghargaan kepada siswa.

Observasi dan evaluasi terdiri atas kegiatan mengobservasi proses pembelajaran dengan menggunakan lembar observasi, mengevaluasi pemahaman siswa dan pemberian respon siswa, dan menganalisis hasil tes dan angket.

Kegiatan refleksi bertujuan untuk mengevaluasi kelemahan-kelemahan, dan hambatanhambatan yang ditemukan dan dianggap mengganjal dalam upaya pencapaian keberhasilan optimal. Prosedur ini akan dilakukan berulang-ulang sampai data yang didapat menunjukkan 
hasil terbaik atau telah memenuhi kriteria keberhasilan yang telah ditentukan dan terjadi peningkatan pada penguasaan pola kalimat bahasa Jepang siswa.

Subjek dalam penelitian ini adalah siswa kelas X IBB 1 sebanyak 36 orang, dipilih sebagai subjek penelitian karena kelas tersebut memiliki kemampuan yang paling rendah dalam menguasai pola kalimat bahasa Jepang sehingga akan memberi pengaruh besar terhadap penguasaan pola kalimat pada jenjang berikutnya. Rendahnya penguasaan pola kalimat bahasa Jepang dikarenakan oleh hal yang telah dikemukakan pada pendahuluan.

Objek dalam penelitian ini adalah penerapan model pembelajaran kooperatif berbantuan media gambar untuk meningkatkan penguasaan pola kalimat bahasa Jepang siswa SMA Candimas Pancasari tahun ajaran 2018/2019.

Metode pengumpulan data merupakan langkah paling utama dalam penelitian karena tujuan utama dari penelitian adalah memperoleh data yang memenuhi standar data yang ditetapkan. Dalam pengumpulan data peneliti menggunakan tiga metode pengumpulan data.

Pertama, untuk mengetahui kemampuan penguasaan pola kalimat siswa, peneliti menggunakan metode tes sebagai penilaian hasil dan metode observasi sebagai penilaian proses. Kedua, metode yang digunakan untuk mengetahui respon siswa, peneliti menggunakan metode angket/kuisioner.

Dalam penelitian tindakan kelas ini, peneliti menggunakan teknik analisis data secara deskriptif kuantitatif dan kualitatif. Analisis deskriptif kuantitatif digunakan untuk menganalisis data mengenai hasil tes penguasaan pola kalimat bahasa Jepang dan data kuesioner tertutup. Sedangkan data hasil angket terbuka dan observasi siswa dianalisis dengan menggunakan teknik deskriptif kualitatif.

Untuk mencari nilai tes setiap siswa, diperlukan sebuah rumus yang sesuai agar data bisa diolah dengan benar. Untuk mengetahui skor evaluasi siswa, dapat dicari dengan rumus sebagai berikut.

$$
\mathrm{N}=\frac{\mathrm{SB}}{\mathrm{TS}} X 100
$$

\section{Keterangan:}

$\mathrm{N}$ : nilai tes yang didapatkan

SB : jumlah soal dijawab benar

TS : jumlah soal seluruhnya

Untuk menentukan nilai rata-rata kelas, maka digunakan rumus sebagai berikut.

$$
\mathrm{M}=\frac{\text { Jumlah Skor Seluruh Siswa }}{\text { Jumlah Seluruh Siswa }}
$$

Keterangan:

$\mathrm{M}:$ Skor rata-rata kelas

Rumus yang digunakan untuk mendapatkan data berupa hasil ketuntasan kelas/klasikal yang dipersentasekan adalah sebagai berikut.

$\mathrm{KK}=\frac{\text { jumlah siswa yang tuntas (sesuai KKM) }}{\text { jumlah siswa yang mengikuti tes }}$

Keterangan:

$\mathrm{KK}$ : ketuntasan klasikal

Untuk penilaian angket akan dilakukan dengan memberikan interpretasi dari jawaban siswa pada setiap butir pertanyaan serta persentasenya. Berikut adalah rumus yang digunakan untuk mengukur persentase setiap jawaban.

$P=\frac{f}{N} X 100 \%$ 
Keterangan:

$P$ : persentase jawaban

frekuensi setiap jawaban

$\mathrm{N}$ : jumlah responden

Untuk pedoman penilaian tanggapan siswa pada angket terbuka sebagai berikut

Tabel 2. Penggolongan respon siswa.

\begin{tabular}{|c|c|}
\hline \multicolumn{1}{l|}{ Skor } & Kriteria \\
\hline $\mathrm{X} \geq 36$ & Sangat Positif \\
\hline $28 \leq X<36$ & Positif \\
\hline $20 \leq X<28$ & Cukup Positif \\
\hline $12 \leq X<12$ & Kurang Positif \\
\hline$X<12$ & Sangat Kurang Positif \\
\hline
\end{tabular}

(Sumber: Nurkancana dan Sunartana, 1992)

Kriteria keberhasilan penelitian ini apabila penguasaan pola kalimat bahasa Jepang siswa melalui penerapan model pembelajaran kooperatif berbantuan media gambar mengalami peningkatan dan adanya sikap antusias siswa dalam pembelajaran. Berdasarkan aturan kriteria keberhasilan yang dinyatakan oleh Heryanto (dalam Pingitasari, 2016) $75 \%$ dari seluruh siswa yang ada di kelas X IBB 1 mendapatkan nilai minimal 75 sesuai dengan Kriteria Ketuntasan Minimal (KKM) pelajaran bahasa Jepang di SMA Candimas Pancasari.

\section{Hasil dan Pembahasan}

Setelah melakukan penelitian mengenai penerapan model pembelajaran kooperatif berbantuan media gambar untuk meningkatkan penguasaan pola kalimat bahasa Jepang siswa kelas X IBB 1 SMA Candimas Pancasari dapat diketahui hasil penelitian sebagai berikut.

Berdasarkan hasil pre-test dalam penguasaan pola kalimat bahasa Jepang siswa kelas X IBB 1 SMA Candimas Pancasari, dapat dilihat dalam tabel berikut.

Tabel 3. Hasil pre-test siswa

\begin{tabular}{|l|l|l|l|l|l|}
\hline NO & Nilai & Frek & $\%$ & Kat & $\begin{array}{l}\text { Ke } \\
\text { t }\end{array}$ \\
\hline 1 & $85-100$ & 0 & 0 & $\mathrm{~A}$ & $\mathrm{~T}$ \\
\hline 2 & $75-84$ & 2 & 5,56 & $\mathrm{~B}$ & $\mathrm{~T}$ \\
\hline 3 & $65-74$ & 2 & 5,56 & $\mathrm{C}$ & $\mathrm{TT}$ \\
\hline 4 & $45-64$ & 7 & 19,44 & $\mathrm{D}$ & $\mathrm{TT}$ \\
\hline 5 & $0-44$ & 25 & 69,44 & $\mathrm{E}$ & $\mathrm{TT}$ \\
\hline Jumlah Skor & \multicolumn{5}{|c|}{$\mathbf{1 0 5 2}$} \\
\hline \multicolumn{4}{|l|}{ Rata-Rata } \\
\hline
\end{tabular}

Keterangan:

Frek = Frekwensi

Kat $=$ Kategori

Ket $=$ Keterangan

$\mathrm{Tt} \quad=$ Tidak Tuntas

$\mathrm{T} \quad=$ Tuntas

Berdasarkan hasil tabel 3 diketahui bahwa ketuntasan klasikal siswa adalah 5,56\%. Secara individual permasalahan yang dialami siswa paling banyak adalah belum mampu 
menguasai penggunaan partikel, menyusun kalimat dengan benar, membuat kalimat tanya dengan benar, dan belum mampu memahami berbedaan penggunaan kata tunjuk benda dan kata tunjuk tempat. Oleh karena itu kelas X IBB 1 SMA Candimas Pancasari layak dijadikan subjek penelitian. Oleh karena itu penelitian ini dapat dilanjutkan ke tahap pelaksanaan siklus.

Pada pelaksanaan siklus I dapat diketahui hasil tes penguasaan pola kalimat bahasa Jepang siswa kelas X IBB 1 sebagai berikut.

Tabel 4. Hasil post-test I siswa

\begin{tabular}{|l|l|l|l|l|l|}
\hline NO & Nilai & Frek & $\%$ & Kat & $\begin{array}{l}\text { Ke } \\
\text { t }\end{array}$ \\
\hline 1 & $85-100$ & 15 & 41,67 & $\mathrm{~A}$ & $\mathrm{~T}$ \\
\hline 2 & $75-84$ & 10 & 27,78 & $\mathrm{~B}$ & $\mathrm{~T}$ \\
\hline 3 & $65-74$ & 4 & 11,11 & $\mathrm{C}$ & $\mathrm{TT}$ \\
\hline 4 & $45-64$ & 7 & 19,44 & $\mathrm{D}$ & $\mathrm{TT}$ \\
\hline 5 & $0-44$ & 0 & 0 & $\mathrm{E}$ & $\mathrm{TT}$ \\
\hline Jumlah Skor \\
\hline \multicolumn{5}{|l|}{ Rata-Rata } & $\mathbf{8 0 9 3}$ \\
\hline
\end{tabular}

Keterangan:

$$
\begin{array}{ll}
\text { Frek } & =\text { Frekwensi } \\
\text { Kat } & =\text { Kategori } \\
\text { Ket } & =\text { Keterangan } \\
\text { TT } & =\text { Tidak Tuntas } \\
\text { T } & =\text { Tuntas }
\end{array}
$$

Berdasarkan tabel 4 diketahui bahwa telah terjadi peningkatan nilai siswa setelah diterapkan model pembelajaran kooperatif hal ini terlihat dari ketuntasan klasikal dari 5,56\% pada pre-test meningkat menjadi $69,44 \%$ pada siklus I. Namun hasil tes pada siklus I belum mencapai ketuntasan klasikal yang telah ditetapkan yaitu $75 \%$. Secara individu kesalahan yang dialami siswa adalah 25 orang siswa (69,44\%) salah dalam menempatkan partikel "no" yang menyatakan kepemilikan, partikel "o" yang menandai aktivitas (kata kerja) dan partikel "de" yang menandai tempat berlangsungnya aktivitas, 14 orang siswa $(38,89 \%)$ salah dalam menempatkan partikel "no" pada kalimat "shuukyou no jugyou wa dou desuka", 20 orang siswa $(55,56 \%)$ terbalik dalam menempatkan kata "koutei de" dengan "nani wo" pada kalimat "koutei de nani wo shimasuka", dan 15 orang siswa $(41,67 \%)$ salah dalam menyusun kalimat "toshoshitsu de bideo wo mimasu", sedangkan yang ditulis siswa "bideo de wo toshoshitsu mimasu". Dibandingkan dengan hasil pre-test siswa tidak lagi mengalami kendala dalam membuat kalimat tanya dalam bahasa Jepang.

Dari hasil analisis post-test I maka perlu dilakukan perbaikan lagi sehingga kriteria ketuntasan yang telah ditetapkan tercapai, maka penelitian ini perlu dilanjutkan pada siklus II.

Berdasarkan hasil respon siswa pada siklus I, dapat dirinci bahwa dari 36 orang siswa yang mengisi angket, ada 18 orang siswa (50\%) memberikan respon positif dan 18 orang siswa (50\%) memberikan respon sangat positif terhadap penerapan model pembelajaran kooperatif berbantuan media gambar dengan hasil rata-rata respon siswa secara keseluruhan sebesar 36 termasuk dalam kategori positif.

Refleksi terhadap pelaksanaan tindakan siklus I adalah sebagai berikut siswa masih belum terlibat secara aktif dalam kegiatan pembelajaran, penjelasan materi terlalu cepat, tidak semua kosakata dari media gambar dapat ditebak oleh siswa, kebingungan dalam penempatan partikel "no", "o", dan "de" serta kata kerja dan kekurangan media gambar. Oleh karena masih terdapat hambatan-hambatan pada siklus I, maka penelitian ini dilanjutkan pada siklus II. Adapun perbaikan yang akan dilakukan pada siklus II sebagai berikut memberikan motivasi positif kepada siswa agar siswa terlibat secara aktif dalam kegiatan 
pembelajaran, memberikan kesempatan bertanya kepada siswa apabila ada penjelasan yang terlewatkan, menjelaskan serta menuliskan dipapan kosakata dari gambar yang tidak diketahui oleh siswa, menjelaskan kembali penggunaan partikel "no", "o", dan "de" serta kata kerja, agar siswa benar-benar memahami dengan baik, dan menambah jumlah media gambar agar lebih memadai saat siswa berlatih membuat kalimat bahasa Jepang.

Setelah dilakukan perbaikan pada siklus II, kegiatan pembelajaran menjadi lebih baik, keaktifan siswa dalam belajar sudah terlihat dan siswa menjadi lebih termotivasi dalam belajar. Secara individual, 3 orang $(8,33 \%)$ masih mengalami kesalahan dalam penempatan partikel, 7 orang $(19,44 \%)$ salah dalam penempatkan kosakata kazoku, otoutosan dan jumlah orang pada kalimat, dan sebanyak 10 orang $(27,78)$ terbalik dalam menggunakan subjek untuk keluarga sendiri dengan keluarga orang lain. Dibandingkan dengan hasil posttest I kesalahan yang dilakukan oleh siswa sudah menurun. Sehingga dapat disimpulkan bahwa penguasaan pola kalimat bahasa Jepang siswa telah mengalami peningkatan yang cukup signifikan. Berikut hasil post-test II siswa.

Tabel 5 hasil post-test II siswa

\begin{tabular}{|l|l|l|l|l|l|}
\hline NO & Nilai & Frek & $\%$ & Kat & $\begin{array}{l}\text { Ke } \\
\mathbf{t}\end{array}$ \\
\hline 1 & $85-100$ & 34 & 94,44 & $\mathrm{~A}$ & $\mathrm{~T}$ \\
\hline 2 & $75-84$ & 2 & 5,56 & $\mathrm{~B}$ & $\mathrm{~T}$ \\
\hline 3 & $65-74$ & 0 & 0 & $\mathrm{C}$ & $\mathrm{TT}$ \\
\hline 4 & $45-64$ & 0 & 0 & $\mathrm{D}$ & $\mathrm{TT}$ \\
\hline 5 & $0-44$ & 0 & 0 & $\mathrm{E}$ & $\mathrm{TT}$ \\
\hline Jumlah Skor & \multicolumn{3}{|c|}{$\mathbf{3 3 8 4}$} \\
\hline \multicolumn{2}{|l}{ Rata-Rata } \\
\hline
\end{tabular}

Keterangan:

$$
\begin{array}{ll}
\text { Frek } & =\text { Frekwensi } \\
\text { Kat } & =\text { Kategori } \\
\text { Ket } & =\text { Keterangan } \\
\text { TT } & =\text { Tidak Tuntas } \\
\text { T } & =\text { Tuntas }
\end{array}
$$

Berdasarkan tabel 5 diketahui bahwa telah terjadi peningkatan penguasaan pola kalimat bahasa Jepang dari $5,56 \%$ pada pre-test, menjadi $69,44 \%$ pada siklus I, dan meningkat lagi menjadi $100 \%$ pada siklus II. Dengan demikian penelitian ini telah mencapai ketuntasan klasikal yang telah ditetapkan yaitu $75 \%$ dan telah terjadi peningkatan penguasaan pola kalimat bahasa Jepang siswa, maka hal tersebut menandakan bahwa penelitian menggunakan penerapan model pembelajaran kooperatif berbantuan media gambar telah berhasil dan dapat dihentikan.

Berdasarkan respon siswa pada siklus II dapat diketahui bahwa 10 orang siswa $(27,78 \%)$ memberikan respon positif dan 26 orang siswa $(72,22 \%)$ memberikan respon sangat positif terhadap penerapan model pembelajaran kooperatif berbantuan media gambar gambar dengan hasil rata-rata respon siswa secara keseluruhan sebesar 37 yang termasuk kedalam kategori sangat positif.

Refleksi terhadap tindakan siklus II dilaksanakan berdasarkan hasil observasi, posttest II dan angket. Pada siklus II proses pembelajaran berlangsung dengan baik hal tersebut dapat diketahui dari hasil ketuntasan klasikal telah mencapai $100 \%$ serta respon siswa terhadap penerapan model pembelajaran kooperatif berbantuan media gambar sangat positif. Hal lainya adalah siswa sudah antusias dalam mengikuti kegiatan pembelajaran, siswa sudah mulai menunjukkan ketertarikan terhadap penjelasan materi, saat kegiatan tanya jawab seluruh siswa sudah mau mengangkat tangan, siswa sudah mampu mengikuti prosedur penerapan pembelajaran kooperatif berbantuan media gambar dengan baik, serta 
memperbaiki kendala-kendala yang terjadi pada siklus I. Perbaikan yang dilakukan pada siklus II menunjukkan siswa memperoleh ketuntasan yang maksimal.

Dari pemaparan tersebut dapat dinyatakan bahwa pelaksanaan siklus II telah mencapai kriteria keberhasilan yaitu $75 \%$ sehingga penelitian dapat dihentikan serta penerapan model pembelajaran kooperatif berbantuan media gambar dapat dikatakan berhasil meningkatkan kemampuan penguasaan pola kalimat bahasa Jepang di kelas X IBB 1 SMA Candimas Pancasari tahun ajaran 2018/2019.

Pembahasan dalam penelitian ini akan memaparkan dua temuan yaitu 1) penerapan model pembelajaran kooperatif berbantuan media gambar untuk meningkatkan penguasaan pola kalimat bahasa Jepang siswa kelas X IBB 1 SMA Candimas Pancasari. 2) respon siswa kelas $X$ IBB 1 SMA Candimas Pancasari terhadap penerapan model pembelajaran kooperatif berbantuan media gambar untuk meningkatkan penguasaan pola kalimat bahasa Jepang

Temuan pertama, berdasarkan hasil pre-test yang dilakukan kepada 36 orang diperoleh nilai rata-rata kelas sebesar 32,88 . Secara individual permasalahan yang dialami siswa paling banyak adalah belum mampu menguasai penggunaan partikel, menyusun kalimat dengan benar, membuat kalimat tanya dengan benar, dan belum mampu memahami berbedaan penggunaan kata tunjuk benda dan kata tunjuk tempat. Hal tersebut menunjukkan bahwa penguasaan pola kalimat bahasa Jepang siswa sangat rendah. hal tersebut didukung oleh ketuntasan klasikal dari seluruh siswa sebesar 5,56\% yang menandakan bahwa hanya 2 orang siswa yang mampu mencapai KKM yang telah ditetapkan yaitu 75 .

Dari permasalahan tersebut, perlu dilakukan sebuah tindakan dalam pelaksanaan pembelajaran agar penguasaan pola kalimat bahasa Jepang siswa meningkat. Tindakan yang dianggap tepat adalah Tindakan Penelitian Kelas (PTK) dengan menerapkan model pembelajaran kooperatif berbantuan media gambar. Pemilihan model dan media pembelajaran tersebut telah disesuaikan dengan karateristik dan kebutuhan siswa kelas $X$ IBB 1.

Pelaksanaan PTK ini dilaksanakan dalam dua siklus dan setiap siklus terdiri dari dua kali pertemuan untuk pemberian materi dan satu kali pertemuan untuk pemberian evaluasi dan angket. Pelaksanaan siklus berdasarkan pada langkah-langkah pembelajaran kooperatif berbantuan media gambar yang telah dirancang dan RPP yang telah disesuaikan dengan silabus bahasa Jepang yang digunakan di kelas X SMA Candimas Pancasari.

Hasil observasi yang diperoleh dari penerapan model pembelajaran kooperatif berbantuan media gambar adalah sebagai berikut. Saat kegiatan belajar secara berkelompok setiap anggota kelompok terlihat saling bertukar informasi dan saling mengoreksi kesalahan temannya saat menyebutkan kosakata dari gambar, selain itu siswa terlihat saling membimbing temannya yang mengalami kendala dan kesalahan saat berlatih membuat kalimat bahasa Jepang dari gambar yang telah dirangakai. Dengan pembelajaran berkelompok (kooperatif) membantu siswa untuk kerjasama dalam menyelesaikan tugas yang diberikan oleh guru dan memberi kesempatan kepada siswa untuk saling membimbing apabila mengalami kendala dalam menguasai pola kalimat bahasa Jepang serta membantu memberi keleluasaan kepada siswa untuk bertukar informasi dengan temannya terkait materi pelajaran (Isjoni,2009:15).

Penerapan model pembelajaran kooperatif juga membantu siswa agar lebih aktif dan menciptakan suasana belajar yang menyenangkan. Pada pelaksanaan siklus I masih ada siswa yang terdiam saat berlatih membuat kalimat bahasa Jepang namun pada siklus II seluruh siswa terlihat antusias dalam membuat kalimat bahasa Jepang. Hal tersebut sejalan dengan yang diungkapkan oleh Asmani (2016:52) yang menyatakan bahwa pembelajaran kooperatif menciptakan suasana kelas menjadi lebih bermakna dan menyenangkan serta memotivasi siswa untuk berperan aktif ketika bekerja sama dalam menyelesaikan setiap tugas yang diberikan oleh guru.

Pemilihan penggunaan media gambar sebagai pendukung dari model pembelajaran kooperatif karena sesuai dengan kondisi sekolah di SMA Candimas Pancasari yang kurang memiliki fasilitas belajar yang memadai. Hal ini sejalan dengan pendapat Setiawati (2013) 
menyatakan bahwa media gambar termasuk media pandang yang tidak diproyeksikan 'non projected media' yaitu media yang saat digunakan tidak memerlukan alat bantu lain, misalnya proyektor untuk melihatnya. Selain itu media gambar digunakan untuk membantu siswa berkonsentrasi, mendorong siswa untuk lebih aktif dan fokus terhadap kegiatan pembelajaran, dan membantu siswa dalam mengingat dan memahami materi pelajaran bahasa Jepang. Hal tersebut sesuai dengan pendapat Levie dan Lentz (dalam Kustandi dan Sutjipto, 2013:20) yang mengemukakan empat fungsi dari media gambar yaitu fungsi atensi untuk membantu menarik perhatian siswa agar lebih berkonsentrasi kepada pembelajaran yang sedang berlangsung, fungsi afektif yaitu memotivasi siswa untuk mendalami materi pelajaran, fungsi kognitif yaitu untuk memudahkan pencapaian tujuan pembelajaran, untuk meningkatkan pemahaman dan daya ingat siswa terhadap materi yang diajarkan, dan fungsi kompensatoris yaitu untuk mengakomodasi siswa yang lambat dalam menerima serta memahami isi pelajaran yang disajikan dengan teks atau verbal.

Setelah dilaksanakan observasi langkah selanjutnya adalah pemberian post-test I kepada siswa untuk mengukur pemahaman siswa terhadap pola kalimat bahasa Jepang yang telah dipelajari. Hasil pada siklus I menunjukkan bahwa nilai rata-rata kelas mengalami peningkatan dari 32,88 pada pre-test menjadi 80,36 pada siklus I. Ketuntasan klasikal siswa juga mengalami peningkatan dari 5,56\% pada pre-test menjadi $69,44 \%$ pada post-test I. Pada siklus I siswa masih mengalami kendala pada penempatan partikel "no" yang menyatakan kepemilikan, partikel "o" yang menandai aktivitas (kata kerja) dan partikel "de" yang menandai tempat berlangsungnya aktivitas. Siswa juga mengalami kendala dalam menempatkan kosakata dalam kalimat, sehingga beberapa kosakata ditempatkan terbalik dalam kalimat bahasa Jepang, namun jika dibandingkan dengan hasil pre-test siswa tidak lagi mengalami kendala dalam membuat kalimat tanya dalam bahasa Jepang.

Peningkatan hasil belajar siswa terjadi setelah diterapkannya model pembelajaran kooperatif berbantuan media. Jika dilihat dari kriteria keberhasilan yang telah ditentukan yaitu sebesar $75 \%$, maka hasil post-test I belum memenuhi kriteria keberhasilan. Oleh karena itu penelitian dilanjutkan ke siklus II agar tercapai kriteria keberhasilan yang telah ditentukan. Selain itu untuk memperbaiki refleksi kegiatan pada siklus I.

Pada siklus II penerapan model pembelajaran kooperatif berbantuan media gambar dilaksanakan dengan bercermin pada refleksi tindakan siklus I. Pelaksanaan siklus II dilaksanakan sesuai dengan perbaikan terhadap kendala atau permasalahan yang terjadi pada siklus I yaitu: 1) pemberian motivasi positif, bimbingan, dan perhatian kepada siswa sehingga seluruh siswa dapat berperan aktif selama kegiatan pembelajaran, 2) memberikan kesempatan bertanya kepada siswa, apabila mengalami kendala dalam memahami materi pola kalimat bahasa Jepang yang telah diajarkan, 3) menuliskan kosakata yang belum diketahui oleh siswa dipapan tulis serta melatih kosakata tersebut dengan menggunakan media gambar, sehingga kosakata tersebut dapat dikuasai oleh siswa dengan baik, 4) menjelaskan kembali perbedaan penggunaan partikel "no", "o", dan "de" beserta penggunaan kata kerja, dan 5) menambah jumlah gambar agar siswa lebih leluasa dalam berlatih membuat kalimat bahasa Jepang

Pelaksanaan kegiatan pembelajaran pada siklus II berlangsung lebih baik dari siklus I. Siswa sudah menunjukkan keaktifan dan ketertarikan terhadap kegiatan pembelajaran, siswa sudah dapat berlatih membuat kalimat bahasa Jepang dengan baik, dan pengelolaan kelas sudah berlangsung dengan baik. Setelah pelaksanaan siklus II, maka dilanjutkan dengan pemberian post-test II. Dari hasil analisis post-test II diperoleh nilai rata-rata kelas dari 80,36 pada post-test I menjadi 94 pada post-test II dengan presentase ketuntasan mencapai $100 \%$. Kesalahan yang dilakukan oleh siswa pada siklus I masih terulang kembali seperti kesalahan penempatan partikel dan kesalahan dalam menempatkan kosakata dalam kalima bahasa Jepang, namun dengan presentase yang lebih sedikit. Dengan demikian penguasaan pola kalimat bahasa Jepang siswa telah mengalami peningkatan

Keberhasilan yang tercapai pada penelitian ini sesuai dengan hasil penelitian yang dilakukan oleh Dewi (2015) yang menyatakan bahwa penerapan model pembelajaran kooperatif efektif dalam meningkatkan pemahaman siswa terhadap pola kalimat bahasa Jepang. Penelitian lainnya yang dilakukan oleh Diner (2009) mengungkapkan bahwa media 
gambar efektif dalam meningkatkan hasil belajar mahasiswa. Dalam penelitian ini terlihat kemampuan siswa dalam memahami pola kalimat mengalami peningkatan pada setiap siklusnya.

Dengan demikian penerapan model pembelajaran kooperatif berbantuan media gambar sangat membantu siswa dalam meningkatkan penguasaan pola kalimat bahasa Jepang pada siswa kelas X IBB 1 SMA Candimas Pancasari.

Temuan kedua adalah siswa memberi respon positif terhadap penerapan model pembelajaran kooperatif berbantuan media gambar. Hal tersebut dapat dibuktikan dari hasil analisis angket pada siklus I diperoleh 18 orang siswa (50\%) memberikan respon positif dan 18 orang siswa (50\%) memberikan respon sangat positif dengan hasil rata-rata respon siswa secara keseluruhan sebesar 36 termasuk dalam kategori positif. Sedangkan hasil analisis angket pada siklus II diketahui bahwa 10 orang siswa $(27,78 \%)$ memberikan respon positif dan 26 orang siswa $(72,22 \%)$ memberikan respon sangat positif dengan hasil rata-rata respon siswa secara keseluruhan sebesar 37 yang termasuk kedalam kategori sangat positif.

Hasil analisis data respon pada penelitian ini sejalan dengan hasil penelitian Dewi (2015) yang mengungkapkan bahwa tanggapan siswa terhadap penerapan pembelajaran kooperatif adalah positif. Respon positif yang diberikan oleh siswa pada penelitian ini menandakan bahwa model pembelajaran kooperatif dapat diterima dengan baik oleh siswa dalam pembelajaran pola kalimat bahasa Jepang.

Dari pemaparan tersebut, secara umum penelitian ini telah mampu menjawab permasalahan yang terdapat pada rumusan masalah. Pembelajaran dengan menerapkan model pembelajaran kooperatif berbantuan media gambar telah berhasil mencapai kriteria ketuntasan yang telah ditentukan. Hal tersebut juga didukung oleh respon positif dari siswa terhadap penerapan model pembelajaran kooperatif berbantuan media gambar.

\section{Simpulan dan Saran}

Berdasarkan hasil analisis dan pengolahan data, nilai rata-rata siswa mengalami peningkatan. Pada pelaksanaan pre-test nilai rata-rata yang didapat 32,88 dengan ketuntasan klasikal hanya $5,56 \%$. Pada siklus I nilai rata-rata siswa meningkat menjadi 80,36 dengan presentase ketuntasan sebesar $69,44 \%$ dan pada siklus II mengalami peningkatan lagi pada nilai rata-rata siswa menjadi 94 dengan ketuntasan klasikal mencapai $100 \%$. Hal tersebut membuktikan bahwa penelitian telah berhasil karena sudah mencapai kriteria keberhasilan yang telah ditetapkan yaitu $75 \%$ pada siklus II.

Berdasarkan hasil analisis data angket dapat disimpulkan bahwa penerapan model pembelajaran kooperatif berbantuan media gambar mendapat respon positif dari siswa dengan rata-rata skor respon 36 pada siklus I yang tergolong positif dan 37 pada siklus II yang tergolong sangat positif.

Berdasarkan temuan-temuan dalam penelitian ini, peneliti dapat menyampaikan beberapa saran, yaitu 1) Untuk siswa dengan penerapan model pembelajaran kooperatif berbantuan media gambar memberikan dampak positif terhadap motivasi, hasil dan prestasi belajar siswa khususnya dalam mempelajari bahasa Jepang. 2) guru hendaknya menjadikan model pembelajaran kooperatif berbantuan media gambar sebagai salah satu metode dalam mengajarkan pola kalimat bahasa Jepang karena tidak hanya efektif untuk meningkatkan prestasi siswa tetapi juga mampu menciptakan suasana pembelajaran menjadi lebih menyenangkan dan memotivasi siswa untuk terlibat aktif dalam kegiatan pembelajaran. 3) bagi peneliti lain agar model pembelajaran kooperatif berbantuan media gambar lebih dikembangkan, sehingga teknik ini tidak hanya digunakan dalam mengajarkan pola kalimat bahasa Jepang tetapi juga untuk mengajarkan huruf, kosakata, sakubun, budaya Jepang maupun yang lainnya.

\section{Daftar Pustaka}

Ahdiyani, Ina. 2015. Penerapan Model Pembelajaran Concept Sentence Dengan Menggunakan Media Flash Card Pada Pembelajaran Pola Kalimat Dasar Bahasa Jepang. Skripsi. Bandung:Universitas Pendidikan Indonesia tersedia pada laman 
http://repository.upi.edu/20197/4/S JEP 1102350 Chapter1.pdf/ (diakses pada tanggal 16 Maret 2019).

Asmani, Jamal Ma'mur. 2016. Tips Efektif Cooperative Learning Pembelajaran Aktif, Kratif, Dan Tidak Membosankan. Yogyakarta: DIVA Press.

Dewi, Komang Try Ayu Candra, dkk. 2015. "Penerapan Model Pembelajaran Kooperatif Berbantuan Media Audio-Visual Untuk Meningkatkan Kemampuan Memahami Tata Bahasa Dasar Bahasa Jepang Siswa Kelas XI IPB 5 SMA Karya Wisata Singaraja Tahun Ajaran 2014/2015". Jurnal Pendidikan Bahasa Jepang Undiksha Vol. 3, No. 1, Edisi 2015. Singaraja : Undiksha. Tersedia pada https://ejournal.undiksha.ac.id/index.php/JJPBJ/article/view/5433 (diakses pada tanggal 13 Juni 2019 ).

Diner, Lispridona. 2009.“Efektivitas Media Gambar Dalam Pengajaran Kuremasu pada Mata Kuliah Struktur (Bunpou) Bahasa Jepang". Jurnal Lembaran IImu Kependidikan Jilid 38, No. 1, Edisi Juni 2009. Semarang: Jurusan Bahasa dan Sastra Asing FBS Unnes. Tersedia pada https://journal.unnes.ac.id/nju/index.php/LIK/article/view/494/451/ (diakses pada tanggal 23 Februari 2019).

Gilies, Robyn. M. 2014. "Cooperative Learning: Developments in Research". International Journal of Educational Psychology, Vol. 3 No. 2 June 2014 pp. 125-140. Australia: The University of Queensland. Tersedia pada http://dx.doi.org/10.4471/ijep.2014.08/ (diakses pada tanggal 18 Februari 2019).

Isjoni. 2009. Pembelajaran Kooperatif Meningkatkan Kecerdasan Komunikasi Antar Peserta Didik. Pustaka pelajar: Yogyakarta.

Istiqomah, Diyah, dkk. 2015."Analisis Kesulitan Belajar Bahasa Jepang Siswa SMK Bagimu Negeriku Semarang". Journal of Japanese Learning and Teaching, volume 4 edisi 1 edisi Juli 2015. Semarang: Universitas Negeri Semarang. Tersedia pada https://journal.unnes.ac.id/sju/index.php/chie/article/view/8422/5644/ (diakses pada tanggal 16 Maret 2019).

Kustandi, Cecep dan Bambang Sujtipto. 2013. Media Pembelajaran Manual dan Digital. Bogor: Ghalia Indonesia.

Mardani, Desak Made Sri. 2012. "Pemanfaatan Media Visual untuk Meningkatkan Kemampuan Menulis Huruf Hiragana dan Katakana". Jurnal pendidikan dan pengajaran Undiksha, Jilid 45, Nomor 3, Edisi Oktober 2012. Singaraja: undiksha. Tersedia pada : https://ejournal.undiksha.ac.id/index.php/JPP/article/view/1836 (diakses pada tanggal 13 Juni 2019).

Pingitasari, Ni Luh Putu Ana. 2016. Penerapan Model Pembelajaran Quantum Teaching Berbantuan Media Kartu Bergambar Untuk Meningkatkan Penguasaan Huruf Hiragana Pada Siswa Kelas X IBB 1 SMA Negeri 3 Singaraja Tahun Ajaran 2015/2016. Skripsi (Tidak Diterbitkan). Singaraja: Universitas Pendidikan Ganesha.

Sanjaya, Wina. 2012. Penelitian tindakan kelas. Jakarta: Kencana Prenada Media Group.

Setiawati, Ai Sumirah. 2005. "Media Gambar Asosiasi Sebagai Salah Satu Alternatif Media Pengajaran Huruf Hiragana". (jurnal ilmiah). Semarang: Jurusan Bahasa dan Sastra Asing FBS UNNES. Tersedia pada Https://Www.Academia.Edu/32050021/MEDIA GAMBAR ASOSIASI SEBAGAI S ALAH SATU ALTERNATIF MEDIA PENGAJARAN HURUF HIRAGANA (diakses tanggal 20 Maret 2019).

Sutedi, D. 2003. Dasar-dasar linguistik bahasa Jepang. Bandung: Humaniora Utama Press. 